\title{
Investigating the effect of matrix acidizing injection pressure on carbonate-rich Marcellus shale core samples: an experimental study
}

\author{
Rayan Khalil ${ }^{1}$ (1) $\cdot$ Hossein Emadi $^{2} \cdot$ Faisal Altawati $^{2}$
}

Received: 12 July 2020 / Accepted: 13 November 2020 / Published online: 29 November 2020

(c) The Author(s) 2020

\begin{abstract}
Near-wellbore damage, which significantly reduces hydrocarbon production, can happen during drilling, cementing, perforation, completion, and stimulation operations. The most common technique to remove or bypass this damage is matrix acidizing. The effects of matrix acidizing injection pressure on acid penetration rate, chemical reaction rate, solubility, porosity, and permeability of Marcellus core samples were investigated in this experimental study. To achieve a successful acid treatment, acid type and concentration must be carefully selected. The results of the X-ray powder diffraction (XRD) and the solubility test revealed that $15 \mathrm{wt} . \%$ hydrochloric acid $(\mathrm{HCl})$ is the optimum acid. Matrix acidizing treatments were implemented on nine core samples, taken from Marcellus (shale gas reservoir), at the reservoir temperature $\left(66^{\circ} \mathrm{C}\right)$, confining pressure of $10.35 \mathrm{MPa}$, and three different acid injection pressures (1.72, 3.45, and 5.17 MPa). The results showed that performing acid treatments on the samples containing continuous carbonate layers created highly permeable channels (wormholes) resulting in significant improvement, up to 3900\%, in the permeability of the samples. Additionally, the results of the acid penetration rate, chemical reaction rate, solubility, porosity, and permeability revealed that increasing the acid injection pressure resulted in increases in the aforementioned properties of the samples. The results also revealed that any increase in the injection pressure above 3.45 MPa did not demonstrate any significant enhancements in the properties of the samples. The results of the XRD analysis revealed that matrix-acidizing treatments dissolved $23.2 \%$ of calcite and $0.4 \%$ of dolomite existed in the samples.
\end{abstract}

Keywords Unconventional resources $\cdot$ Matrix acidizing $\cdot$ Effective porosity $\cdot$ Permeability enhancement

\section{Introduction}

According to EIA (2015), the US oil and gas production from unconventional reservoirs, which have ultimate-low permeability (microdarcies to nanodarcies), has been tremendously improved since 2007. Even though horizontal drilling and multistage-hydraulic fracturing are necessary to produce with economical rates from such reservoirs (King 2011; Mohanty et al. 2019; Warpinski et al. 2009; Zoback and Kohli 2019), the oil and gas production rates significantly decrease by $90 \%$ in the first two to three years of

Rayan Khalil

rayan_051@hotmail.com

1 Faculty of Earth Sciences, King Abdulaziz University, Jeddah, Saudi Arabia

2 Texas Tech University, Lubbock, USA production (Zoback and Kohli 2019). Despite implementing horizontal drilling and multi-stage hydraulic fracturing, unconventional oil and gas recovery factors are still ultimatelow, $10 \%$ in oil reservoirs and $25 \%$ in gas reservoirs (Teklu et al. 2019; Zoback and Kohli 2019). Also, implementing hydraulic fracturing treatments requires a substantial amount of water, which puts additional stress on local water resources.

Pa Derrick, on October 10, 1895, reported the first acid treatment implemented on an oil well (Knox 1973), demonstrating that matrix acidizing is the oldest stimulation treatment (Tambini 2003), which is still used in the oil and gas industry. However, acid treatment had not been considered a commercial stimulation treatment until 1932, when an inhibitor was discovered that can effectively limit the equipment corrosion in the fields (Hendrickson et al. 1971).

Two types of acid stimulation treatment can enhance reservoirs permeability and production rates: matrix acidizing 
and acid fracturing. Matrix acidizing is to inject acid below a formation fracturing pressure. The objective of matrix acidizing is to improve or restore the near-wellbore permeability, a radius of $20-61 \mathrm{~cm}(8-24$ inches $) \mathrm{cn}$ without fracturing the producible formations (King 1986), and this radius might be $5 \mathrm{ft}$ in the carbonate reservoirs (Mcleod 1989). By removing the near-wellbore damage that reduces formation permeability, the production rate can be increased ten to hundreds of times (King 1986). Removing the nearwellbore damage results in significant improvement in the production rate, if the damage is close to the perforations (Nino-Penaloza and Gomaa 2016).

In undamaged formations, however, it is uncommon to increase the production rate by implementing matrix acidizing treatments. On the other hand, acid fracturing is injecting acid above a formation fracturing propagation pressure to create fractures. Unlike matrix acidizing, fracture acidizing can be successfully implemented in undamaged formations to create long fractures deep into the formation to bypass the formation damage. It is an alternative treatment for hydraulic fracturing in carbonate formations with low permeability and/or deep damage (Knox and Ripley 1979). To keep the fractures open, fracture faces must be etched in nonuniform shapes to create conductive flow channels.

Several acid types have been developed, but the most common ones are inorganic acids: hydrochloric acid $(\mathrm{HCl})$ and hydrochloric/hydrofluoric acid (HCl/HF) (Coulter 2012; Coulter and Jennings Jr 1997). $\mathrm{HCl}$ is commonly used to increase permeability in carbonate or carbonate-rich shale formations (such as Marcellus shale and Eagle Ford shale). It chemically reacts with limestone $\left(\mathrm{CaCO}_{3}\right)$ and the byproducts of the chemical reaction are water-soluble (Aldakkan et al. 2018): calcium chloride $\left(\mathrm{CaCl}_{2}\right)$, carbon dioxide $\left(\mathrm{CO}_{2}\right)$, and water $\left(\mathrm{H}_{2} \mathrm{O}\right)$ [Eq. (1)]. The byproducts of the chemical reaction between $\mathrm{HCl}$ and dolomite are $\mathrm{CaCl}_{2}$, magnesium chloride $\left(\mathrm{MgCl}_{2}\right), \mathrm{CO}_{2}$, and water [Eq. (2)].

$\mathrm{CaCO}_{3}+2 \mathrm{HCL} \rightarrow \mathrm{CaCl}_{2}+\mathrm{CO}_{2}+\mathrm{H}_{2} \mathrm{O}$.

$\mathrm{CaMg}\left(\mathrm{CO}_{3}\right)_{2}+4 \mathrm{HCL} \rightarrow \mathrm{CaCl}_{2}+\mathrm{MgCl}_{2}+\mathrm{CO}_{2}+\mathrm{H}_{2} \mathrm{O}$

$\mathrm{HCl}$ reacts with limestone faster than dolomite (Carpenter 2014; Patton et al. 2003). The acid reaction rate has a direct relationship with temperature. $\mathrm{HCl}$ reaction rate with limestone at a reservoir temperature of $60-66{ }^{\circ} \mathrm{C}$ is approximately double than at $27^{\circ} \mathrm{C}$ (Coulter Jr et al. 1987; Kalfayan 2008).

On the other hand, hydrofluoric (HF) acid treatments we successfully implemented in Monterey shale formation, a quartz-rich shale formation (Trehan et al. 2012). Additionally, Rowe et al. (2004) successfully acidized 49 vertical and 19 horizontal shale wells, and as a result, the average oil production of the horizontal wells increased up to ninefold, while the average vertical well production increased by 110 barrels of oil per day (BOPD) and more than 500 thousand standard cubic feet per day (MSCF/D). The second acid type is organic acids (formic and acetic acids) that are considered weak acids (Chang et al. 2008). These acids are used in specific conditions including high-temperature formations, where $\mathrm{HCl}$ corrosion is high, and high iron chlorite formations. Acetic acid, for example, can be used to remove calcium carbonate scale (Mcleod 1989). In some cases, a mixture of inorganic and organic acids could be used to reduce the reaction rate, which increases the acid penetration depth.

Near-wellbore damage might occur during drilling, cementing, completion, perforation, and/or production operations (Harry and Mcleod 1984). The degree of success of a matrix acidizing treatment depends on the presence of the damage and its distance from the wellbore. There are three main types of formation damage, in which two of them are related to the formation rock (Coulter and Jennings 1999). Absolute permeability damage occurs when solid particles, such as drilling mud particles, occupy all or a portion of the pore spaces resulting in a reduction in the formation permeability. To eliminate this permeability reduction, the damage zone must be either removed or bypassed (Coulter and Jennings 1999). Reduction in the hydrocarbon relative permeability resulting from the presence of injection fluid(s), causes a reduction of the hydrocarbon production rate.

Matrix acidizing in carbonates or carbonate-rich shale formations helps remove near-wellbore damage and improve near-wellbore permeability by enlarging pore throats (Coulter and Jennings 1999). Matrix acidizing creates conductive flow channels (wormholes), which are substantially more permeable than the reservoir rock. Consequently, fluids can easily flow from the formation into the wellbore through these wormholes overcoming near-wellbore damage and low permeability zones. The results of the experimental study conducted by Khalil et al. (2017) demonstrated that performing matrix acidizing using $15 \% \mathrm{HCl}$ on Eagle Ford (a carbonate-rich shale formation) core samples considerably enhances the permeability of the core samples (from nanodarcies to microdarcies).

Up to the present, several studies have investigated the efficacy of the matrix acidizing technique on shale reservoirs. Using a new placement technique, Trehan et al. (2012) implemented matrix acidizing on a Monterey shale well using hydrofluoric (HF) acid because the main mineral composition is quartz. The new method can be used to pump liquids as high as 11.7 barrels per minute (bbl/min) with a pumping time of $5.1 \mathrm{~h}$.

Morsy et al. (2013) investigated the effects of hydrochloric acid $(\mathrm{HCl})$ on porosity, spontaneous imbibition, and crack distribution in shale samples from Eagle Ford, Mancos, Barnett, and Marcellus shale formations. Various 
acid concentrations of 4,15 , and $20 \%$ were used in that study, and the results revealed that $4 \% \mathrm{HCl}$ was the optimum one to enhance porosity and oil recovery without damaging the structures of the core samples. Also, they recommended that low concentration $\mathrm{HCl}$ can penetrate deeply in shale formation as part of the hydraulic fracturing process in addition to being used around the wellbore.

Tripathi and Pournik (2014) experimentally investigated the effect of matrix acidizing on four core samples (3.81 cm in diameter and $15.24 \mathrm{~cm}$ in length) from Eagle Ford shale formation. The average mineralogical compositions of the core samples were mainly: calcite (48.8\%), siderite $(18.1 \%)$, and dolomite $(11.9 \%)$. They submerged the samples in $15 \% \mathrm{HCl}$ for $24 \mathrm{~h}$ at atmospheric pressure and ambient temperature. The results revealed that the acid dissolved an average of $38 \%$ of the core samples leading to increasing the effective porosities of the core samples.

Khalil et al. (2017) studied the effect of matrix acidizing treatments on four oil-saturated Eagle Ford shale core samples with different lengths $(1.27,2.54,3.81$, and $5.08 \mathrm{~cm}$ ). The results of the solubility test demonstrated that $15 \% \mathrm{HCl}$ is the optimal acid concentration for matrix acidizing purposes. The results also revealed that implementing the acid treatments increased the fracture widths in addition to increasing the permeability of the core samples from 1.04 nanodarcies (nd) to an average of 2.1 microdarcies $(\mu \mathrm{d})$. They stated that matrix acidizing enhanced gas flooding treatments. However, they noticed early breakthrough in gas flooding treatments after conducting matrix acidizing on the core samples.

$\mathrm{Wu}$ and Sharma (2017) evaluated the matrix acidizing on one preserved core from Bakken shale. The results of the XRD tests revealed that $24 \%$ of the core sample was calcite, while $27 \%$ was quartz. Approximately, $35 \%$ of the Bakken powder sample was dissolved by $50 \mathrm{~mL}$ of $3 \mathrm{wt} . \%$ $\mathrm{HCl}$ and $3 \mathrm{wt} . \% \mathrm{KCl}$. Also, the acid changed the microstructure, pore structure, and mechanical properties of the shale sample. Clay, quartz, and organic matters are structurally stable minerals in acidizing treatments. However, they can be dislodged in $\mathrm{HCl}$ if surrounding carbonates get dissolved. Acidizing formed macropores with a diameter of $120 \mu \mathrm{m}(\mu \mathrm{m})$ which increased the fracture conductivity and reduced the hardiness of the shale fracture surface by $30-70 \%$. As a result, the permeability and porosity increased which may enhance the hydrocarbon flow.

Teklu et al. (2019) investigated the effect of 1 and 3\% $\mathrm{HCl}$ diluted in $10 \% \mathrm{KCl}$ (potassium chloride) brine on porosity and permeability of 48 Canadian shale core samples from Otter Park (14 samples), Muskwa (23 samples), and Evie (11 samples) formations. The core samples were wrapped by tape, and the top and bottom sides of the core samples were in contact with 1 or $3 \% \mathrm{HCl}$ acid (three times the rock mass) at room conditions for four days.
The results revealed that $\mathrm{HCl}$ enhanced the porosity and permeability of the core samples.

Sheng et al. (2019) evaluated the effects of the acidizing treatments on two types of core samples from Longmaxi marine and Yanchang continental shale formations (China) using an acid mixture of $15 \% \mathrm{HCl}$ and $3 \% \mathrm{KCl}$ for $10 \mathrm{~h}$. Carbonate contents of the core samples from Longmaxi and Yanchang were $27 \%$ and $26 \%$, respectively, while the clay contents were $18 \%$ and $4 \%$, respectively. Each core sample was immersed in $5 \mathrm{~cm}^{3}$ of the acid mixture for two hours, and they were dried at room temperature $\left(26^{\circ} \mathrm{C}\right)$ for $24 \mathrm{~h}$ without using any heat source. The results revealed that the acid dissolved carbonate minerals resulting in creating cracks and connecting the pore spaces. This phenomenon was observed in carbonates, anhydrite, and clay minerals, and as a result, the generated tensile stress and increased the porosities of the samples.

Using 0.5 to 15 wt. $\% \mathrm{HCl}$, Singh et al. (2019) stimulated calcite-rich Eagle Ford shale samples. They claimed that the conductivity of unpropped fractures of the shale core samples significantly increased by $4000 \%$ after conducting the acidizing treatments. They also mentioned that the increment of the shale conductivity increased when the acid concentration increased.

Wu et al. (2020b) experimentally examined the effects of acid treatments on the mechanical properties of shale samples (Barnett, Eagle Ford, Haynesville, and Utica). They observed that samples with high carbonate content have more etched surfaces, which is related to the distribution pattern of the carbonate content inside the samples. Due to the acid etching, the hardness of the shale samples decreased by $54.5 \%$ (200-400 MPa).

Wu et al. (2020a) conducted a simulation acid fracturing research to study the effects of acid fracturing on unpropped fractures in shale samples with different carbonate contents. The results revealed that acid fracturing treatments enhanced the rich-carbonate shale conductivity by creating channels due to the viscous fingering of carbonate vein.

Marcellus shale formation is a good candidate for matrix acidizing treatments owing to possessing high carbonate content. The results of XRD tests conducted by Gupta and Mishra (2017) and Piane et al. (2018) revealed that Marcellus core samples contain 75\% and 80-90\% calcite, respectively. Additionally, Crandall et al. (2018) CT-scanned Marcellus formation (Tippens 6HS Well) and claimed that Marcellus reservoir has several calcareous sections, calcite veins, and calcite clasts. They also demonstrated that the formation has more than $40 \%$ calcite in some sections. Hence, matrix acidizing can be a stimulation method in such reservoirs.

Economides et al. (2013) stated that the results of acidizing treatments in laboratory scales cannot be expected to predict the response in field scales, but it should be used

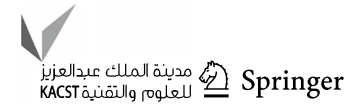


in the field as a guideline. Also, they recommended more careful selections of optimal acid by conducting laboratory tests using core samples with different acid concentrations. Thus, the main objective of this research, as the first comprehensive research, is to experimentally investigate the effect of matrix acidizing injection pressure on acid penetration rate, chemical reaction rate, solubility, porosity, and permeability of carbonate-rich (Marcellus) shale core samples at the reservoir temperature $\left(66^{\circ} \mathrm{C}\right)$.

The samples were divided into three groups; each group had one sample containing continuous carbonate layers, while the other two had discontinuous carbonate layers. Using the results of the XRD and solubility test, $15 \mathrm{wt} . \%$ $\mathrm{HCl}$ was selected as the optimal acid in this research. After heating the samples to the reservoir temperature $\left(66^{\circ} \mathrm{C}\right)$ and applying the confining pressure of $10.35 \mathrm{MPa}$, the acid was injected into the samples at three different pressures of 1.72 , 3.45, and 5.17 MPa. Finally, after drying the core samples, the solubility, porosity, and permeability of the core samples were measured to study the effects of the matrix-acidizing on the properties of the samples.

\section{Materials and methodology}

Nine Marcellus outcrop core samples $(3.81 \mathrm{~cm}$ in diameter and $5.08 \mathrm{~cm}$ in length) cut parallel to the bedding were used in this study. Both end-faces of the core samples were polished to assure flat edges, and their dimensions were measured using a digital caliper.

NL3000 CereTom X-ray CT scanner was used to scan the core samples prior to and after implementing the matrix acidizing treatments. The $\mathrm{CT}$ scanner has a minimum recognizable slice volume of $0.1225 \mathrm{~mm}^{3}(1 \mathrm{~mm}$ slice thickness), a spatial resolution of $0.35^{*} 0.35 \mathrm{~mm}$, and a relative density resolution of $0.3 \% \mathrm{Hu}$. The results of the CT-scan tests were used to identify any existing carbonate layer(s) and fracture(s) in the core samples.

The conventional method of measuring the porosity of core samples involves a low injection pressure $(0.7 \mathrm{MPa})$ that may introduce errors in the porosity results of the unconventional core samples. Khalil et al. (2019), however, investigated the optimum injection pressure to measure the porosity of unconventional core samples. They used four different injection pressures $(0.69,1.38,2.07$, and $2.76 \mathrm{MPa})$ to measure the porosity of unconventional core samples using helium. The results revealed that the optimum injection pressure to measure the porosity of the shale core samples is $1.38 \mathrm{MPa}$ and any increase in the pressure beyond that value did not significantly affect the results but might crack the samples. Hence, all the porosity measurements were conducted using helium at $1.38 \mathrm{MPa}$.
Permeabilities of the core samples were measured using complex transient method and AutoLab 1500 triaxial cell, capable of measuring permeability as low as five nanodarcies (nd). After applying a confining pressure of $5.17 \mathrm{MPa}$, helium was injected at $1.73 \mathrm{MPa}$ from the upstream side until the downstream pressure transducer reads the same pressure, which may take up to $48 \mathrm{~h}$ depending on the sample permeability. Because of the ultralow permeability of the core samples (nanodarcies), it took up to eight weeks for the core samples to reach the pressure equilibrium at the reservoir conditions of $66{ }^{\circ} \mathrm{C}$ and $29.2 \mathrm{MPa}$ confining pressure. Hence, confining pressure and pore pressure of 5.17 MPa and $1.73 \mathrm{MPa}$, respectively, were applied at ambient temperature $\left(22^{\circ} \mathrm{C}\right)$ to conduct the permeability tests.

Since the acid treatment resulted in creating wormholes inside the core samples, which substantially increase their permeability, the complex transient method could not be used to calculate the permeability of the samples after implementing the acid treatment. Hence, Darcy's law was used to measure the permeability of the core samples.

Since the rock mineralogy dictates the type of acid used in an acid treatment operation, XRD tests were conducted on the core samples to determine their mineralogical compositions. Figure 1 demonstrates that the core samples are composed of $69.8 \%$ calcite, $28.5 \%$ quartz, $1.2 \%$ dolomite, and $0.5 \%$ pyrite. Since the core samples were mainly composed of calcite, $\mathrm{HCl}$ was chosen as the appropriate acid type in this study.

To determine the optimal acid concentration, solubility tests must be conducted on the core samples. $\mathrm{HCl}$ acid with different concentrations $(5 \%, 10 \%, 15 \%, 20 \%$, and $25 \%$ ) was added to five ground core samples ( $27 \mathrm{~g}$ each). The samples were left for $24 \mathrm{~h}$ (until there was no indication of acid reaction with the samples). Then, the samples were dried using a vacuum oven (at $66{ }^{\circ} \mathrm{C}$ for $24 \mathrm{~h}$.) and weighed. Finally, the solubility is calculated using Eq. (3):

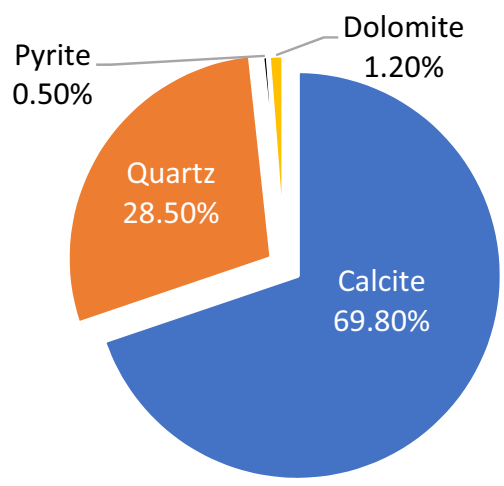

Fig. 1 Mineralogical compositions of the core samples 
Solubility $=\frac{(\text { Initial Weight }- \text { Final Weight })}{\text { Initial Weight }} * 100$.

Figure 2 illustrates that higher acid concentration leads to higher solubility since the higher concentration acid dissolved more of the crushed samples. The results also indicated that any increase in the acid concentration above $15 \%$ does not significantly improve the solubility of the sample. An increase in acid concentration from 15 to $25 \%$ resulted in an increase of only $2 \%$ in the solubility. Furthermore, most of the available inhibitors lose their effectiveness when $\mathrm{HCl}$ concentration exceeds $17 \%$. Hence, $15 \% \mathrm{HCl}$ was selected as the optimal acid concentration in this study.

The core samples were divided into three groups based on their density, porosity, and permeability to study the effect of the acid injection pressure on their porosity, permeability, solubility, chemical reaction rate, and acid penetration rate. Table 1 shows that each group had one core sample containing continuous calcite layers and two core samples containing discontinuous calcite layers. Figure 3 illustrates that the setup consisted of a syringe pump to apply confining pressure, a core holder, a heating tape to heat the core samples, a Quizix pump to inject the fluids, an accumulator to contain $\mathrm{HCl}$, two pressure gauges to measure the confining and the injection pressures. Each core sample was placed inside the core holder, and confining pressure of $10.34 \mathrm{MPa}$ was then applied.

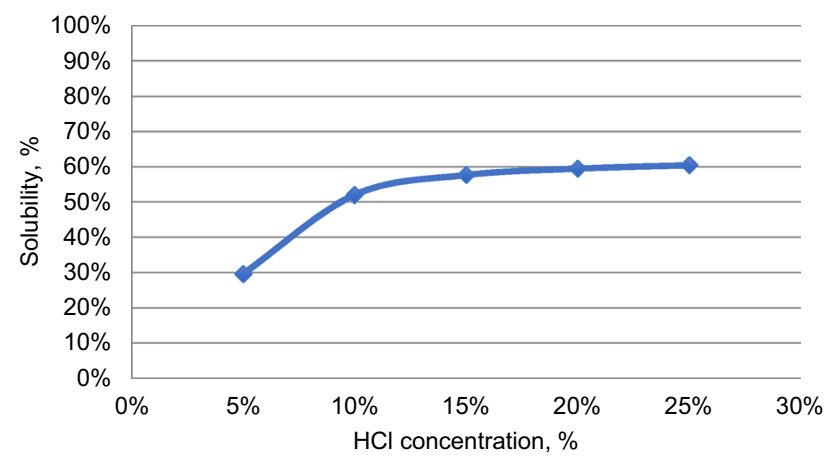

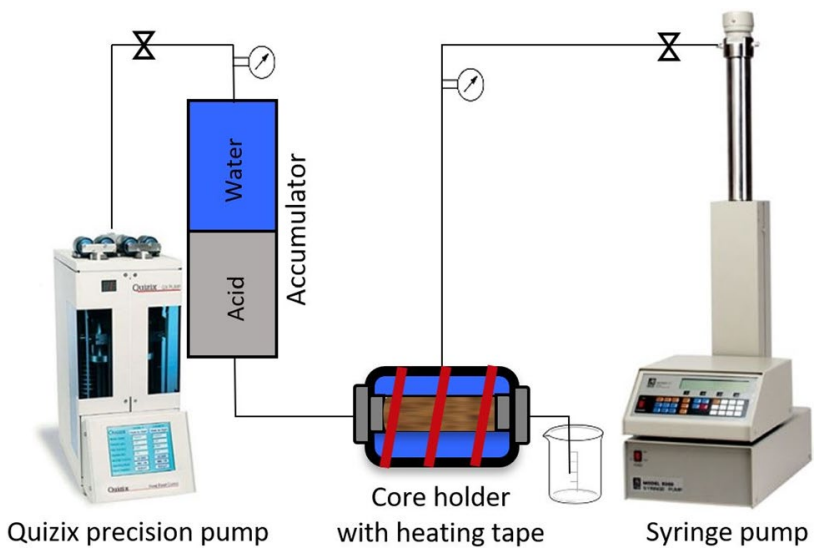

Fig. 3 Matrix acidizing setup

The core holder was heated up to the reservoir temperature of $66^{\circ} \mathrm{C}\left(150^{\circ} \mathrm{F}\right)$ afterward. According to the heat transfer calculations, it took three hours and seventeen minutes for the whole setup to reach the temperature of $66{ }^{\circ} \mathrm{C}$ from the room temperature of $22^{\circ} \mathrm{C}\left(71^{\circ} \mathrm{F}\right): 26 \mathrm{~min}$ for the stainless-steel core holder, $160 \mathrm{~min}$ for the confining water between the core holder and the rubber sleeve, $3 \mathrm{~min}$ for the rubber sleeve, and $8 \mathrm{~min}$ for the core sample. However, to assure that the whole system reached the temperature equilibrium, the core holder was left at $66^{\circ} \mathrm{C}$ for $12 \mathrm{~h}$. Then, the acid was injected into each group of the samples at pressures of 1.72, 3.45, and 5.17 MPa. Due to safety concerns, the acid was injected into the core sample either until the breakthrough is observed or for four hours. Moreover, $\mathrm{HCl}$ strongly reacts with carbonate as shown in Eq. (1) and (2), and as a result, carbonate layers are dissolved in the solution. The rate of this reaction, which depends on the dissolved mass and the duration of the reaction, is calculated using Eq. (4).

Rate of Reaction $=\frac{\text { mass lost }(\text { grams })}{\text { time }(\text { minutes })}$

Fig. $2 \mathrm{HCl}$ solubility of crushed samples

Table 1 Properties of the core samples

\begin{tabular}{|c|c|c|c|c|c|c|c|c|c|}
\hline \multirow[b]{2}{*}{ Sample \# } & \multicolumn{3}{|c|}{ Group 1} & \multicolumn{3}{|c|}{ Group 2} & \multicolumn{3}{|c|}{ Group 3} \\
\hline & M5 & M6 & M9 & M2 & M7 & M8 & M1 & M3 & M4 \\
\hline Calcite layer continuity & Yes & No & No & Yes & No & No & Yes & No & No \\
\hline Density, $\mathrm{g} / \mathrm{cm}^{3}$ & 2.62 & 2.61 & 2.62 & 2.61 & 2.62 & 2.62 & 2.61 & 2.62 & 2.62 \\
\hline Avg. density, $\mathrm{g} / \mathrm{cm}^{3}$ & 2.62 & & & 2.62 & & & 2.62 & & \\
\hline Porosity, \% & 9 & 8 & 11 & 10 & 7 & 11 & 9 & 10 & 9 \\
\hline Avg. porosity, $\%$ & 9 & & & 9 & & & 9 & & \\
\hline Permeability, nd & 59 & 8 & 29 & 153 & 14 & 6 & 5 & 85 & 9 \\
\hline Avg. permeability, nd & 32 & & & 58 & & & 33 & & \\
\hline
\end{tabular}




\section{Results and discussion}

Figure 4 demonstrates that the $\mathrm{HCl}$ breakthrough was only observed on the core samples having continuous carbonate layers, which left highly conductive channels (wormholes). Additionally, Fig. 5 shows that the acid penetration rate has a proportional relationship with the acid injection pressure due to the increase in the reaction rate of the acid and the calcite layers. The penetration rate was $4.86,6.43$, and 6.86 $10-4 \mathrm{~cm} / \mathrm{s}$ at injection pressures of $1.72,3.45$, and $5.17 \mathrm{MPa}$, respectively. On the other hand, Fig. 6 does not show continuous wormholes since the breakthrough was not observed in the core samples possessing discontinuous carbonate layers. Due to the density difference among the minerals in the core samples, Figs. 7a and 8a demonstrate that calcite beddings can be easily identified using the results of the CT-scan tests, in which brighter colors represent higher densities. After completing the matrix acidizing treatments, Fig. 7b demonstrates that calcite layers have been dissolved in the acid leaving a wormhole as wide as the calcite layer. Figure $7 \mathrm{c}$ shows that the uneven shape of the wormhole edges will keep the flow path open without using proppants. On the other hand, Fig. 8 shows that the acid could not create any continuous wormhole in the samples that did not possess any continuous layer(s).

Increasing the acid injection pressure caused the acid to penetrate deeper into the core samples which increased the stimulated volume, and as a result, increased the reaction rate, solubility, porosity, and permeability of the core samples. Figure 9 illustrates that the chemical reaction rate of the core samples at $\mathrm{HCl}$ injection pressure of $1.72,3.45$, and $5.17 \mathrm{MPa}$ was $0.112,0.158$, and $0.161 \mathrm{~g} / \mathrm{min}$, respectively. This chemical reaction dissolved up to $21 \%$ of the calcite of the core samples which produced byproducts of calcium

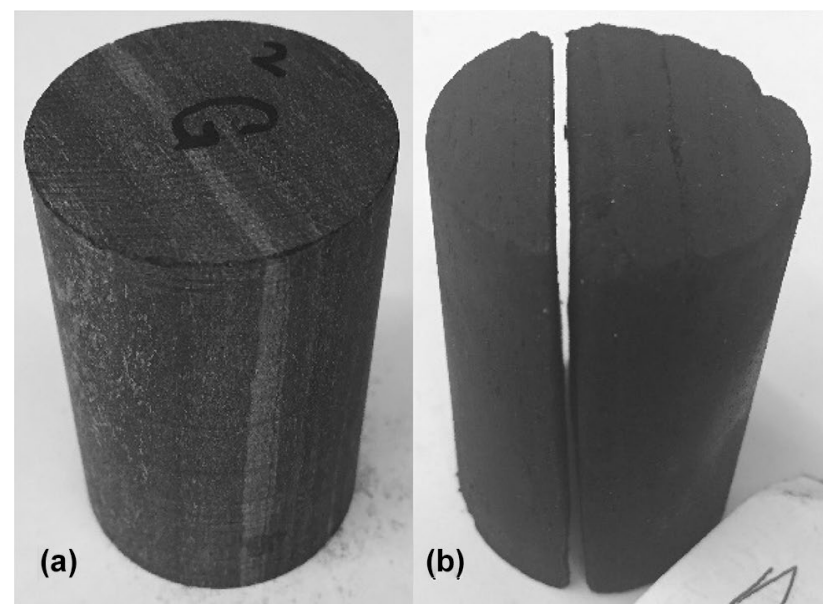

Fig. 4 A core sample having continuous calcite layer $\mathbf{a}$ before and $\mathbf{b}$ after the acid treatment

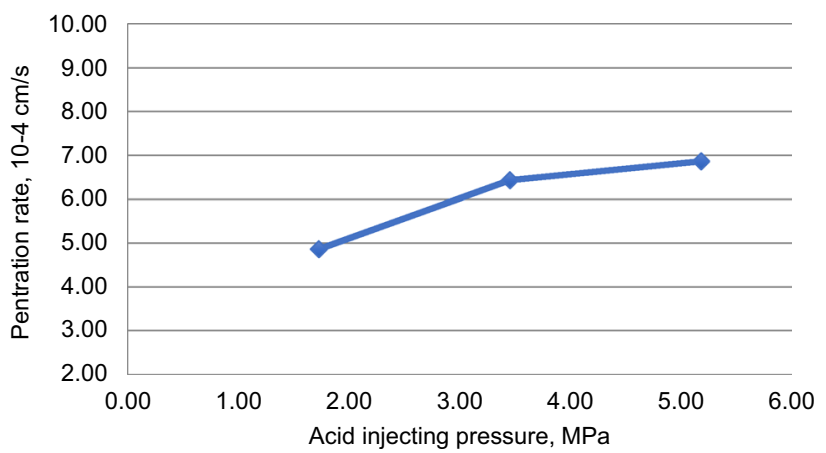

Fig. $5 \mathrm{HCl}$ Acid penetration rate at different acid injection pressures

chloride (dissolvable salt in water), water, and carbon dioxide. Figure 10 shows that the solubility of the core samples was $17 \%, 20 \%$, and $21 \%$ when the acid was injected at 1.72 , 3.45, and 5.17 MPa, respectively, and as a result, the effective porosity of the core samples was increased by $9 \%, 12$, and $13 \%$, respectively (Table 2 and Fig. 11). Additionally, injecting the acid into the core samples possessing continuous layers of calcite resulted in dissolving the calcite layer(s) and halving the samples, which made the permeability measurement impossible. However, the permeability of one core sample (M5), out of three acidized core samples that had continuous calcite layers, was successfully measured using the Klinkenberg effect method. Figure 12 shows that the absolute permeability of the core sample M5 after the matrix acidizing is 2.32 darcies, while it was 59 nanodarcies before the acidizing. The significant increase in the permeability of the samples resulted from forming the wormhole after implementing the acid treatment. Table 2 and Fig. 13 demonstrate that the matrix acidizing treatments significantly increased the permeability of the core samples containing discontinuous calcite layers as well and increasing the acid
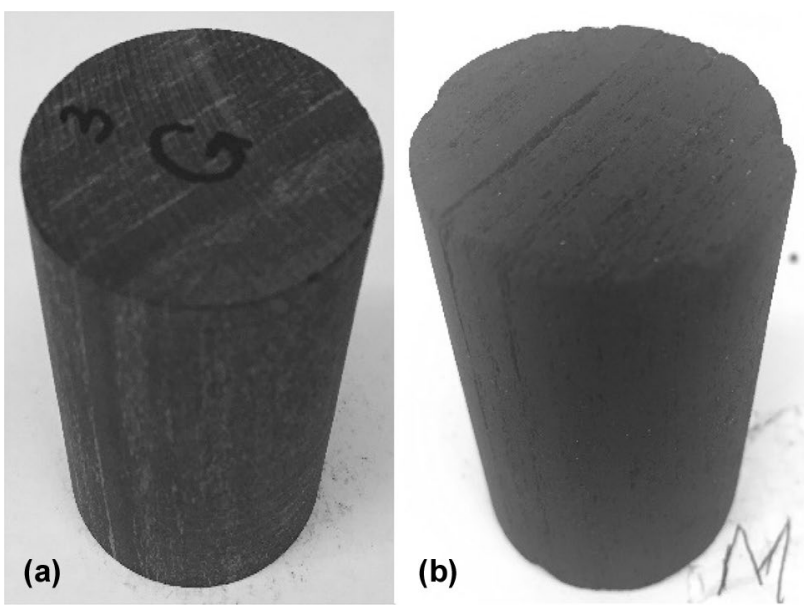

Fig. 6 A core sample having discontinuous calcite layer a before and b after the acid treatment 
Fig. 7 CT-scan of a core sample having a continuous calcite layer $\mathbf{a}$ before $\mathbf{b}$ after the acid treatment

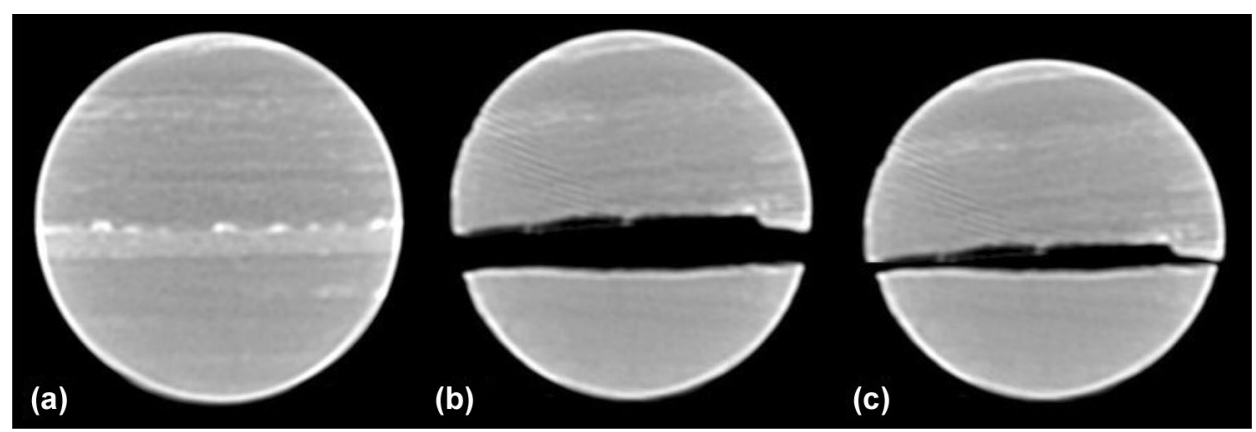

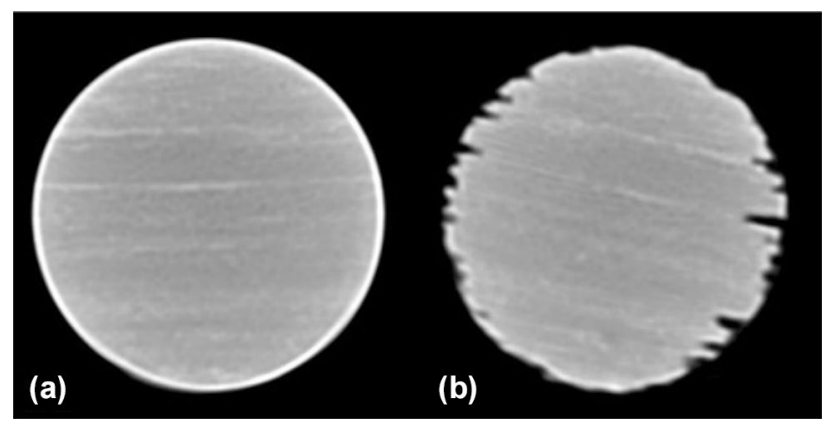

Fig. 8 CT-scan of a core sample having discontinuous calcite layer a before $\mathbf{b}$ after acid treatment

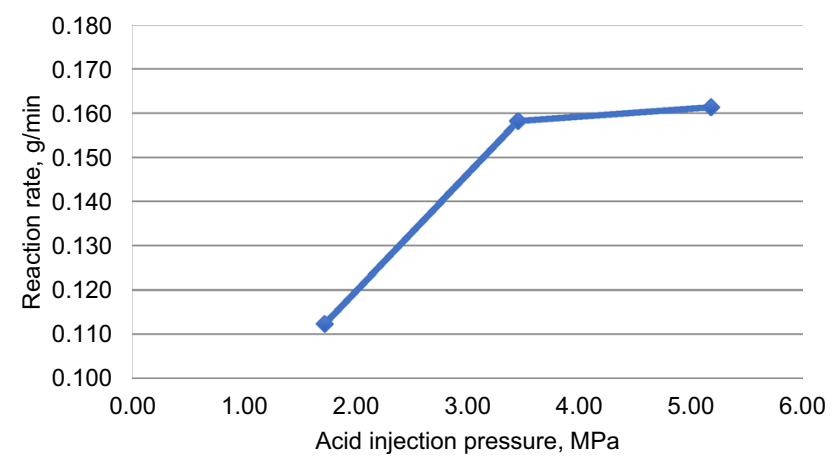

Fig. 9 The reaction rate of $\mathrm{HCl}$ with the core samples at different acid injection pressures

injection pressure increased the permeability of the core samples owing to dissolving calcite present in the samples. Figure 13 shows that the permeability of the core samples, having discontinuous carbonate layers, after acidizing is 313 , 361 , and 374 millidarcy when the acid was injected at 1.72 , 3.45 , and $5.17 \mathrm{MPa}$, respectively. It is worth noting that the results of the acid penetration rate, chemical reaction rate, solubility, porosity, and permeability of the core samples did not reveal significant enhancements above the acid injection pressure of 3.45 MPa. It is most likely because the acid did not significantly penetrate deeper into the core samples due to the low permeability of the core samples.

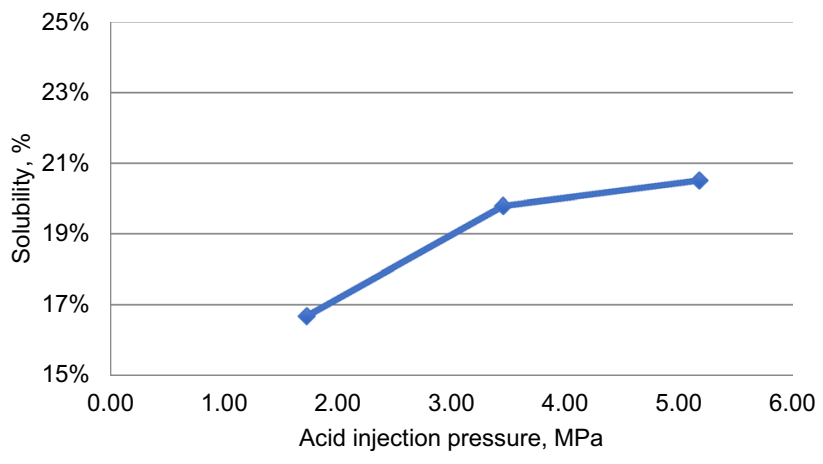

Fig. 10 The solubility of the core samples at different acid injection pressures

The results of the XRD test before implementing the matrix acid treatments revealed that $69.8 \%$ of the core samples is calcite, $28.5 \%$ is quartz, $1.2 \%$ is dolomite, and $0.5 \%$ is pyrite. After implementing the matrix acidizing treatment, the mineralogical compositions were altered owing to the carbonate dissolution in the acid. Figure 14 shows that after completing the treatments the core samples are composed of $54.9 \%$ calcite, $42.7 \%$ quartz, $0.8 \%$ dolomite, and $0.5 \%$ pyrite. The results also demonstrated that $32.21 \%$ of the calcite and $0.4 \%$ of the dolomite have been dissolved leaving $23.61 \%$ extra pore spaces inside the core samples resulting in porosity and permeability enhancements.

\section{Conclusions}

The efficacy of the matrix acidizing treatments on shale core samples at the confining pressure of $10.34 \mathrm{MPa}$ and reservoir temperature $\left(66^{\circ} \mathrm{C}\right)$ was investigated in this research study. The concept behind the shale matrix acidizing is to create high conductive channels (wormholes) when $\mathrm{HCl}$ acid dissolves calcite layers in carbonate-rich formations such as Marcellus and Eagle Ford, USA. These wormholes will stimulate near-wellbore and fracture-face zones, and as a result, increase hydrocarbon production. The results of the XRD and solubility tests demonstrated 
Table 2 Porosities of core samples before and after matrix acidizing treatments
Fig. 11 Porosity increase after performing acid treatments at different acid injection pressures

\begin{tabular}{|c|c|c|c|c|c|c|c|c|c|}
\hline \multirow{3}{*}{$\begin{array}{l}\text { Item } \\
\text { Acid injection pressure, } \mathrm{MPa} \\
\text { Sample \# }\end{array}$} & \multirow{2}{*}{\multicolumn{3}{|c|}{$\frac{\text { Group } 1}{1.72}$}} & \multirow{2}{*}{\multicolumn{3}{|c|}{$\frac{\text { Group } 2}{3.45}$}} & \multirow{2}{*}{\multicolumn{3}{|c|}{$\frac{\text { Group } 3}{5.17}$}} \\
\hline & & & & & & & & & \\
\hline & M5 & M6 & M9 & M2 & M7 & M8 & M1 & M3 & M4 \\
\hline Porosity before the treatment, $\%$ & 9 & 8 & 11 & 10 & 7 & 11 & 9 & 10 & 9 \\
\hline Porosity after the treatment, $\%$ & 22 & 15 & 18 & 29 & 18 & 17 & 29 & 22 & 16 \\
\hline Avg. Porosity before the treatment, $\%$ & 9 & & & 9 & & & 9 & & \\
\hline Avg. Porosity after the treatment, $\%$ & 18 & & & 21 & & & 22 & & \\
\hline Increase in porosity, $\%$ & 9 & & & 12 & & & 13 & & \\
\hline Permeability before the treatment, nd & 59 & 8 & 29 & 153 & 14 & 6 & 5 & 85 & 9 \\
\hline Avg permeability before acid, nd & 32 & & & 58 & & & 33 & & \\
\hline Permeability after the treatment, $10^{6} \mathrm{nd}$ & 2,317 & 492 & 133 & N/A* & 538 & 185 & N/A* & 640 & 107 \\
\hline Avg permeability after acid, $10^{6} \mathrm{nd}$ & 313 & & & 361 & & & 374 & & \\
\hline
\end{tabular}

N/A*: Permeability could not be measured because the acid treatment dissolved the calcite layers and separated the core sample into two halves

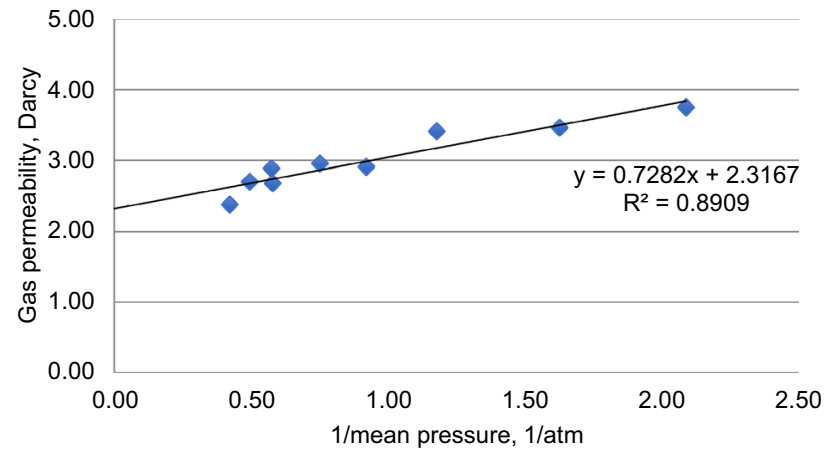

Fig. 12 Absolute permeability using Klinkenberg effect method

that $15 \% \mathrm{HCl}$ is the optimum acid type and concentration for Marcellus core samples. The results revealed that injecting $15 \% \mathrm{HCl}$ into Marcellus shale samples increases their porosities and permeability. However, permeability enhancement is substantially more significant in the samples containing continuous calcite layers(s) owing to high permeability wormholes ( 2.3 darcy) resulting from $\mathrm{HCl}$ breakthrough than the samples containing discontinuous carbonate layer(s). The results also revealed that matrix
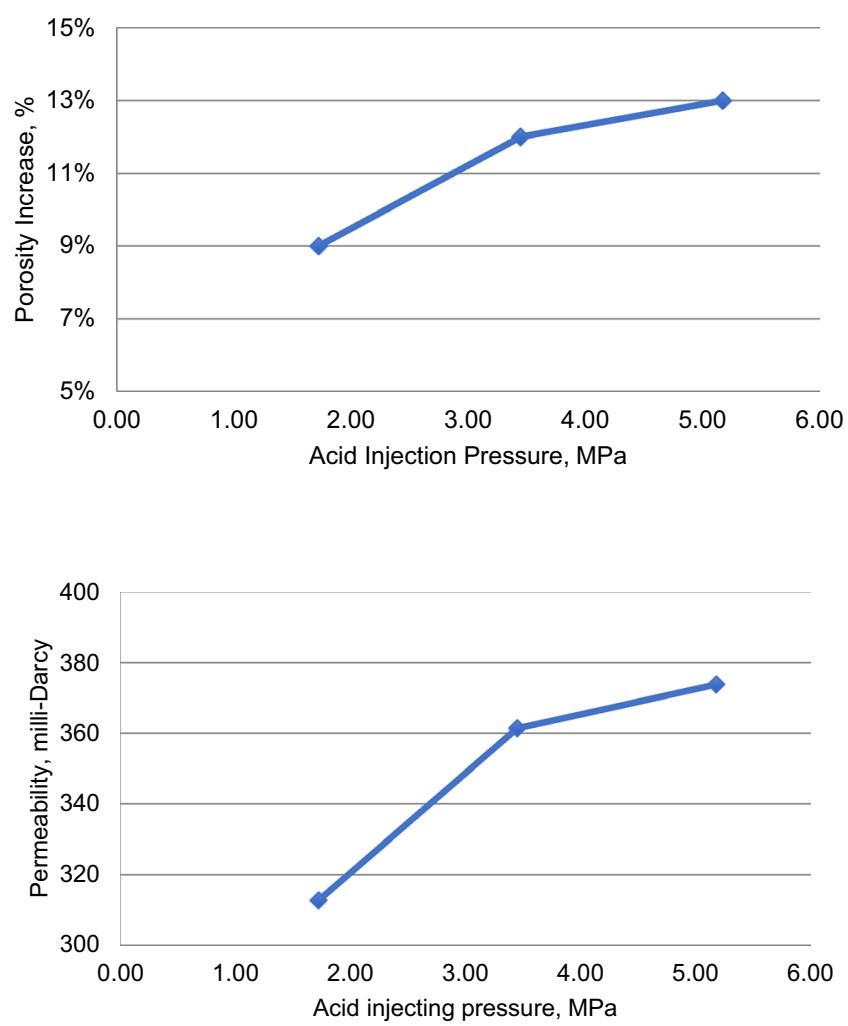

Fig. 13 Average permeability of the samples (had discontinuous calcite layers) after completing the acid treatments

acidizing increased the porosity of the core samples, possessing discontinued calcite layers, by up to $13 \%$ and enhanced the average permeability of the samples from 41 nanodarcies to 349 millidarcy. Furthermore, the results showed that increasing the acid injection pressure resulted in increases in porosity, permeability, solubility, reaction rate, and acid penetration rate of the samples. Additionally, the results demonstrated that increasing the injection 


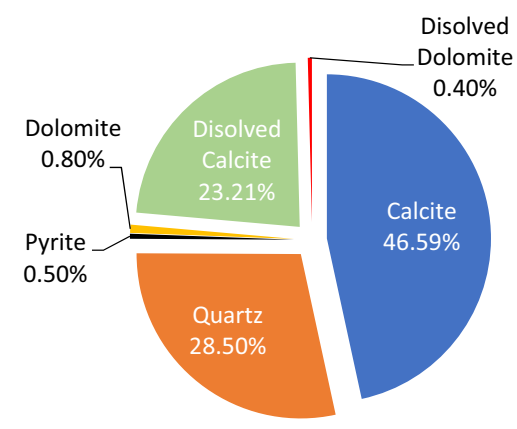

Fig. 14 Mineralogical compositions of the core samples after acid treatments

pressure above $3.45 \mathrm{MPa}$ does not significantly improve the porosity and permeability of the samples.

Acknowledgements The authors would like to thank Elena Melchert (Director of the Upstream Oil and Gas Research Division of the U.S. Department of Energy), Dr. Dustin Crandall (a Research Engineer at the National Energy Technology Laboratory), and Robert Vagnetti of the National Energy Technology Laboratory for providing the core samples.

Funding The core samples were provided from the U.S. Department of Energy (DOE).

Open Access This article is licensed under a Creative Commons Attribution 4.0 International License, which permits use, sharing, adaptation, distribution and reproduction in any medium or format, as long as you give appropriate credit to the original author(s) and the source, provide a link to the Creative Commons licence, and indicate if changes were made. The images or other third party material in this article are included in the article's Creative Commons licence, unless indicated otherwise in a credit line to the material. If material is not included in the article's Creative Commons licence and your intended use is not permitted by statutory regulation or exceeds the permitted use, you will need to obtain permission directly from the copyright holder. To view a copy of this licence, visit http://creativecommons.org/licenses/by/4.0/.

\section{References}

Aldakkan B, Al Moajil AM, Alnoaimi K (2018) Carbonate acidizing and flowback analysis-a review and an evaluation method, IADC/ SPE asia pacific drilling technology conference and exhibition. Society of Petroleum Engineers

Carpenter C (2014) Effect of low-concentration hydrochloric acid on properties of shale rocks. J Petrol Technol 66(10):172-176

Chang FF, Nasr-El-Din HA, Lindvig T, Qui X (2008) Matrix acidizing of carbonate reservoirs using organic acids and mixture of $\mathrm{HCl}$ and organic acids, SPE Annual Technical Conference and Exhibition. Society of Petroleum Engineers

Coulter G (2012) Technology focus: well stimulation (June 2012). J Petrol Technol 64(06):90-90

Coulter G, Jennings Jr A (1997) A contemporary approach to matrix acidizing, SPE annual technical conference and exhibition. society of petroleum engineers

Coulter GR, Jennings AR Jr (1999) A Contemporary approach to matrix acidizing. SPE-56279-PA 14(02):144-149
Coulter Jr A, Hendrickson A, Martinez S (1987) Acidizing (1987 PEH Chapter 54). Petroleum engineering handbook

Crandall D et al (2018) CT scanning and geophysical measurements of the marcellus formation from the tippens 6HS Well, National energy technology lab.(NETL), Morgantown, WV (United States)

Economides MJ, Hill AD, Ehlig-Economides C, Zhu D (2013) Petroleum production systems. Pearson education

EIA U (2015) Drilling productivity report for key tight oil and shale gas regions

Gupta N, Mishra B (2017) Creep characterization of marcellus shale, 51st US Rock Mechanics/geomechanics symposium. American Rock Mechanics Association.

Harry O, Mcleod J (1984) Matrix acidizing. SPE J 36:2055-2069

Hendrickson A, Rosene R, Alderman E (1971) Acidizing: fact and fiction, annual technical meeting. Petroleum society of Canada

Kalfayan L (2008) Production enhancement with acid stimulation. Pennwell books

Khalil R, Emadi H, Elwegaa K (2019) Investigation of rock properties of the marcellus formation-an experimental study, SPE Eastern Regional Meeting. Society of petroleum engineers

Khalil RE, Mansour A, Gamadi T (2017) An experimental study of acid matrix treatment performance on shale core samples, SPE Liquids-Rich Basins Conference-North America. Society of Petroleum Engineers

King GE (1986) Acidizing concepts-matrix versus fracture acidizing. J Petrol Technol 38(05):507-508

King H (2011) Hydraulic fracturing of oil and gas wells drilled in shale. Geology. com

Knox J, Ripley H (1979) Fracture acidizing in carbonate rock. J Can Pet Technol 18(04)

Knox JA (1973) Acidizing-past, present, and future, annual technical meeting. Petroleum society of Canada

Mcleod HO (1989) Significant factors for successful matrix acidizing, SPE Centennial Symposium at New Mexico Tech. Society of Petroleum Engineers

Mohanty KK et al (2019) Improved hydrocarbon recovery using mixtures of energizing chemicals in unconventional reservoirs. SPE Reservoir Evaluation and Engineering

Morsy S, Sheng J, Hetherington C, Soliman MY, Ezewu RO (2013) Impact of matrix acidizing on shale formations, SPE Nigeria Annual International Conference and Exhibition. Society of petroleum engineers

Nino-Penaloza A, Gomaa AM (2016) New insights on chemical diversion in carbonate acidizing: experimental and simulationbased study, SPE annual technical conference and exhibition. society of petroleum engineers

Patton BJ, Pitts F, Goeres T, Hertfelder G (2003) Matrix acidizing case studies for the Point Arguello Field, SPE Western regional/ AAPG pacific section joint meeting. Society of Petroleum Engineers

Piane CD et al (2018) Contrasting anisotropy of velocity and electric/dielectric response in the Marcellus and Utica Shales, SEG Technical Program Expanded Abstracts 2018. Society of Exploration Geophysicists, pp 3608-3612

Rowe G, Hurkmans R, Jones N (2004) Unlocking the Monterey Shale potential at Elk Hills: a case study, SPE international thermal operations and heavy oil symposium and western regional meeting. Society of Petroleum Engineers

Sheng M et al (2019) Mineral cracking and porosity enhancement of shale through acidizing, asia pacific unconventional resources technology conference, Brisbane, Australia, 18-19 November 2019. Unconventional resources technology conference, pp $1122-1142$

Singh R, Tong S, Panthi K, Mohanty K (2019) Stimulation of calciterich shales using nanoparticle-microencapsulated acids. SPE J

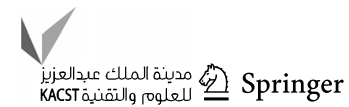


Tambini M (2003) Beyond acidizing and fracturing, SPE European formation damage conference. Society of petroleum engineers

Teklu TW, Park D, Jung H, Amini K, Abass H (2019) Effect of dilute acid on hydraulic fracturing of carbonate-rich shales: experimental study. SPE Prod Oper 34(01):170-184

Trehan R, Jones ND, Haney JA (2012) Acidizing optimization: monterey shale, California, SPE Western Regional Meeting. Society of petroleum engineers

Tripathi D, Pournik M (2014) Effect of acid on productivity of fractured shale reservoirs, Unconventional Resources Technology Conference, Denver, Colorado, 25-27 August 2014. Society of Exploration Geophysicists, American Association of Petroleum, pp 1811-1823

Warpinski NR, Mayerhofer MJ, Vincent MC, Cipolla CL, Lolon E (2009) Stimulating unconventional reservoirs: maximizing network growth while optimizing fracture conductivity. J Can Pet Technol 48(10):39-51

Wu W, Russell R, Sharma M (2020) Non-uniform etching-the key for an effective acid fracturing in shale: an experimental study. In: Unconventional Resources Technology Conference (URTEC)
Wu W, Sharma MM (2017) Acid fracturing in shales: effect of dilute acid on properties and pore structure of shale. SPE Prod Oper 32(01):51-63

Wu W, Szabian M, Sharma M (2020). Effect of acid etching on surface topography, mechanical properties and fracture conductivity in shale. In: Unconventional resources technology conference (URTEC).

Zoback MD, Kohli AH (2019) Unconventional reservoir geomechanics. Cambridge University Press, Cambridge

Publisher's Note Springer Nature remains neutral with regard to jurisdictional claims in published maps and institutional affiliations. 